\title{
A Produção Científica Sobre Formação dos Policiais Militares no Brasil
}

\section{Celia Cristina Pereira da Silva Veiga}

Possui graduação em Pedagogia, pela Universidade Federal Rural do Rio de Janeiro (2013) e graduação em Teologia, pelo Seminário Teológico Batisto do Sul do Brasil (2014). É Mestre em Educação pela UFRRJ (2016) e Doutorondo em Educação pelo pelo Programa de Pós-graduação em Educaçõo, Contextos Contemporâneos e Demandas Populares do Universidade Federal Rural do Rio de Janeiro. É membro do grupo de pesquisa GTPS - Trabalho, Política e Sociedade e da Rede Universitas, que é vinculada ao GT-11 do ANPED e policial militar do estado do Rio de joneiro.

\section{José dos Santos Souza}

Professor associado III de Economia Política da Educação e de Política Educacional do Departamento de Educação e Sociedade do Instituto Multidisciplinar da Universidade Federal Rural do Rio de Janeiro, onde atua como docente do Programa de Pós-Graduação em Educação Contextos Contemporâneos e Demandas Populares (PPGEduc/UFRRJ) e de cursos de licenciaturas. É Líder do Grupo de Pesquisas Sobre Trabalho, Político e Sociedade (GTPS/UFRRJ), integro a Rede Universitas-BR, é membro associado da ANPEd e do ANPAE.

\begin{abstract}
Data de recebimento: $18 / 06 / 2017$
Data de aprovação: 03/08/2018

DOI: 10.31060/rbsp.2018.v12.n1.813
\end{abstract}

\section{Resumo}

A partir de levantamento e revisão bibliográfica, neste trabalho, busca-se explicitar tendências do debate científico acerca do formação do policial militar no período de 2001 a 2015. Neste período, foram identificados 12 artigos, 23 dissertações e 08 teses abordando a formação do policial militar. Deste conjunto, o currículo utilizodo na formação desses policiais foi o temo mais recorrente (mais de 50\%), seguido de "Direitos Humanos" e de discussões acerca do coerêncio entre o conteúdo curricular e sua aplicação no cotidiano do trabalho do policial militar.

\section{Palavras -Chave}

Formaçõo Militor. Polício Militar. Seguranço Público. 


\section{Abstract}

The Scientific Production About Iroining the Militory Police in Brozil

From literature review, this paper seeks to explain trends in the scientific debate about the military police officers' training from 2001 to 2015. In this period were raised 12 articles, 23 dissertations and 08 theses addressing the training of the military police. In this set, the curriculum used in the training of these police officers was the most recurrent theme (over 50\%), followed by the "Human Rights" and discussions about the consistency between the curriculum content and its application in the daily routine of military police officers.

\section{Keywords}

Militory Training. Militory Police. Public Sofety. 


\section{INTRODUÇÃO}

crise do capital desencadeada a partir do
final da década de 1960 e início da década de 1970 foi impulsionada pelo esgotamento do regime de acumulaçáo fordista e pelo desgaste das ideias keynesianas em tensão com o projeto neoliberal (Cf. HOBSBAWN, 1977; MÉSZÁROS, 2002; HARVEY, 2007; 2011; HAYEK, 2010; FRIEDMAN, 1984). Essa crise determinou o desenvolvimento de ofensivas do bloco no poder para manutençáo de suas bases de acumulaçáo corroídas pela crise (SOUZA, 2015b). Duas principais frentes dessa ofensiva foram: a reestruturaçáo produtiva que visava a reorganizaçáo do processo produtivo desenvolvendo o regime de acumulaçáo flexível (Cf. HARVEY, 2007; 2011; SOUZA, 2015a; 2015b; PINTO, 2007) e a reforma do Estado que visava a reorganizaçáo da administraçáo pública (SOUZA, 2015a; 2015b).

O processo de reforma do Estado impulsionado nos países de regime capitalista, a partir da década de 1970, infundiu um novo modelo de administraçáo pública. A Nova Gestão Pública
(NGP), orientada pelo discurso da qualidade na prestaçáo do serviço, está fundamentada no modelo empresarial, com os objetivos de racionalizar e flexibilizar a administraçáo pública. Com base nessa reforma do Estado, a administraçáo pública tem passado por mudanças orientadas pelo gerencialismo que afetam todas as instituiçóes públicas. Consequentemente, as instituiçóes que prestam serviço de segurança pública também foram impactadas pela reforma do Estado, a começar pela concepção de segurança pública.

Um dos principais reflexos do gerencialismo para segurança pública diz respeito à proposiçáa de um conceito de segurança pública voltado à prestaçáo de serviço e à gestão de conflitos. Novos modelos de policiamento que tomam esse ideal como base foram adotados desde então, como a polícia comunitária e o policiamento orientado para resoluçáo de conflitos, sobretudo a partir da década de 1990 (REINER, 2000; BITTNER, 2003). A Organização das Naçóes Unidas (ONU) passou a infundir o conceito de "Segurança Cidadä"1 e desenvolver diversas medidas para adoçáo desse conceito, principal-

1 Segundo o Programa das Nações Unidas para o Desenvolvimento (PNUD), a segurança cidadã consiste na proteção de um núcleo de direitos básicos, como o direito ò vida, o respeito à integridade física e material da pessoo e seu direito a uma vida digna (ONU, 2013). Tal conceito está centrado no bem-estar das pessoas e considera que a provisão da segurança cidadã é um requisito indispensóvel ao desenvolvimento humano (ONU, 2013). As características elencadas para a segurança cidadã são coincidentes com o conceito de policiamento comunitário e de policiamento orientado para resolução de problemas, de modo que podemos dizer que configuram 
mente nos países da América do Sul. O desenvolvimento da Matriz Curricular Nacional para Açóes Formativas dos Profissionais da Área de Segurança Pública² (MCN) (BRASIL, 2009) foi uma das açóes impulsionadas por tal projeto político internacional para segurança pública. $\mathrm{O}$ desenvolvimento de um curríaulo que fundamente conceitualmente a formaçáo policial no Brasil serve, dentre outros objetivos, para difusáo do conceito de segurança pública encampado pela $\mathrm{ONU}^{3}$.

Nesse contexto de mudanças infundidas para segurança pública, a produçáo de pesquisas acadêmicas explicita as tendências em desenvolvimento eserve para esclarecer como o tema tem sido abordado cientificamente. Portanto, objetivo aqui é, a partir da revisáo de literatura das pesquisas em nível de pós-graduaçáo, estabelecer um percurso analítico que nos permita indicar como a abordagem acerca da formaçáo policial militar tem sido tratada na literatura da área das ciências humanas ${ }^{4}$, sobretudo na área da educação, tendo em vista tratar-se de educaçáo profissional.

A metodologia utilizada para realização do levantamento e revisáo bibliográfica foi desenvolvida por meio de etapas para coleta, catalogação, leitura, sistematizaçáo e análise dos dados coletados. As etapas que serviram de base para o desenvolvimento da pesquisa, nessa ordem, foram: escolha do tema; delimitaçáo das palavras-chave; determinaçáo das bases de dados para pesquisa; determinaçáo das categorias para sistematizaçáa das pesquisas encontradas; busca das pesquisas disponíveis nos bancos de dados e classificação a partir das categorias elencadas; sistematizaçáo dos dados das pesquisas sobre o tema escolhido; análise dos resumos das pesquisas; desenvolvimento do relatório a partir da análise dos dados encontrados (ROMANOWSKI e ENS, 2006; SEVERINO, 2007; MARCONI e LAKATOS, 2003).

A abordagem que desenvolvemos aqui é iniciada pela análise quantitativa da produçáo de pesquisas sobre a formaçáo policial militar no Brasil. Tal análise serve para delinear o universo da pesquisa a partir dos elementos disponíveis nos bancos de dados pesquisados. Em seguida, abordamos a essa produçáo a partir dos principais temas encontrados, a fim de compreender os reflexos da política de segurança pública delineada no contexto da reforma gerencial sobre a produção de pesquisas na área.

duas nomenclaturas para o mesmo objeto. Segundo o PNUD, a segurança cidadã oferece novas possibilidades para enfrentar os aspectos multicausais da violência, potencializa a governança democrática local, desenvolve capacidades para a promoção da segurança e da cultura cidadã, estimula o participação comunitária no desenvolvimento das atividades policiais, reorienta e ajusta ações à realidade territorial e facilito o prestação de contos (ONU, 2013).

2 A MCN foi elaborada no âmbito do Projeto Segurança Cidadõ - ação conjunta realizada entre a Organização das Nações Unidas (ONU) e o Ministério da Justiça, no âmbito da Secretaria Nacional de Segurança Pública (SENASP) - com a participação das instituições de segurança pública do país. Essa matriz curricular tem como objetivo organizar a política pedagógica e o currículo para formação profissional do agente de segurança pública em torno do conceito de "segurança cidadã".

3 o aprofundamento da relação entre reforma do Estado e desenvolvimento de uma série de ações voltadas para segurança pública, mais especificamente paro o formação do policial militar, foi desenvolvido em trabalhos anteriores (Cf.: VEIGA, 2016; VEIGA; SOUZA, 2016). Portanto, em respeito aos limites deste artigo, nõo nos detivemos aqui na análise dessa questõo. 4 Após a conclusão deste artigo, foi publicado o resultado de um amplo levantamento acerca da produção bibliográfica na área de segurança pública que explicito os tendêncios do debate acerco do tema (MUNIZ; CARUSO; FREITAS, 2018). 


\section{A Literatura e a Questão da Formação Policial Militar}

O levantamento bibliográfico foi realizado no período de 16 de março a 26 de maio de 2015, a partir do acervo disponibilizado nos sites do Scientific Electronic Library Online (SciELO); IndexadorOnline de Periódicos na Área da Educaçáo (Educ@), da Fundaçáo Carlos Chagas Filho; dos trabalhos apresentados em reunióes anuais da Associaçáa Nacional de Pesquisa e Pós-graduação em Educaçáo (ANPED); do Banco Nacional de Dissertaçóes e Teses Digitais (BDTD) do Instituto Brasileiro de Informaçáo em Ciência e Tecnologia (IBICT); e do Catálogo de Teses e Dissertaçóes da Coordenaçáa de Aperfeiçoamento de Pessoal do Ensino Superior (CAPES). Essas bases foram escolhidas porque são as principais bases de acervo de pesquisas científicas em nível nacional.

Após consulta ao Thesaurus Brasileiro da Educaçáo (INEP, 2015), tomamos as palavras-chave: "policial militar"; "polícia militar"; "polícias militares"; "policiais militares"; "formação do Policial Militar"; "PMERJ”; "PM RJ'; "soldado Policial Militar"; "CFSD”; "segurança pública”; "curso de formaçáo de soldado"; "educaçáo policial"; "ensino policial”; "escola policial"; "pedagogia policial"; "treinamento policial"; "formaçáo policial"; e, "Polícia Militar do Estado do Rio de Janeiro". Tais palavras-chave serviram como parâmetro de busca em todas as bases de dados mencionadas.

Os resultados das pesquisas por palavra-chave foram categorizados a partir de temas: "formaçáo"; "cultura”; "violência policial"; "saúde policial”; "história”; "gestáo”; "prática policial”; "ética”; "etnia”; "gênero"; "política”; "sociedade"; "náo pertinente"; e, "outros". A leitura dos títulos e dos resumos permitiu tal categorizaçáo que possibilitou-nos visualizar os temas que estão presentes em maior número e relevância nas pesqui- sas na área de segurança pública.

Tendo em vista o quantitativo de trabalhos e a demanda de conhecer o período que marcou o início da produçáo científica na área, não foi delimitado um recorte temporal inicial específico. Portanto, o resultado obtido espelha toda produçáo na área constante nos bancos mencionados. Ao final do levantamento notamos que as pesquisas disponíveis para consulta têm origem a partir de 2001. Por isso, para efeitos de recorte temporal, estabelecemos após a realizaçáo do levantamento, o período de 2001 a 2015.

O total geral de trabalhos publicados nas cinco bases de dados mencionadas anteriormente foi de 1.954 trabalhos que utilizaram as palavras-chave descritas, conforme discriminado no Gráfico 01. Esse número não exclui as repetiçōes, que foram depuradas na segunda fase.

Logo de início, uma primeira constatação que nos chamou à atençáo foi a ausência total de pesquisas sobre a formaçáo do policial militar nas reuniōes anuais da Associaçáo Nacional de Pós-graduação e Pesquisa em Educação (ANPED), desde que iniciou suas atividades. Esta constataçáo nos deixa dúvidas sobre o interesse dos educadores do país em participar mais efetivamente do debate a respeito do tema que perpassa não apenas a sociedade como um todo, mas o próprio universo escolar na atualidade, haja vista, inclusive, o emprego de policiais militares nas escolas públicas em diversos estados brasileiros, por meio de programas de segurança e resistência às drogas, como por exemplo, o Programa Educacional de Resistência às Drogas (PROERD) e programas que dispóem de policiamento ostensivo no interior das escolas, sobretudo no estado do Rio de Janeiro, onde destacamos o Programa Estadual de Integraçáo na Segurança (PROEIS). 


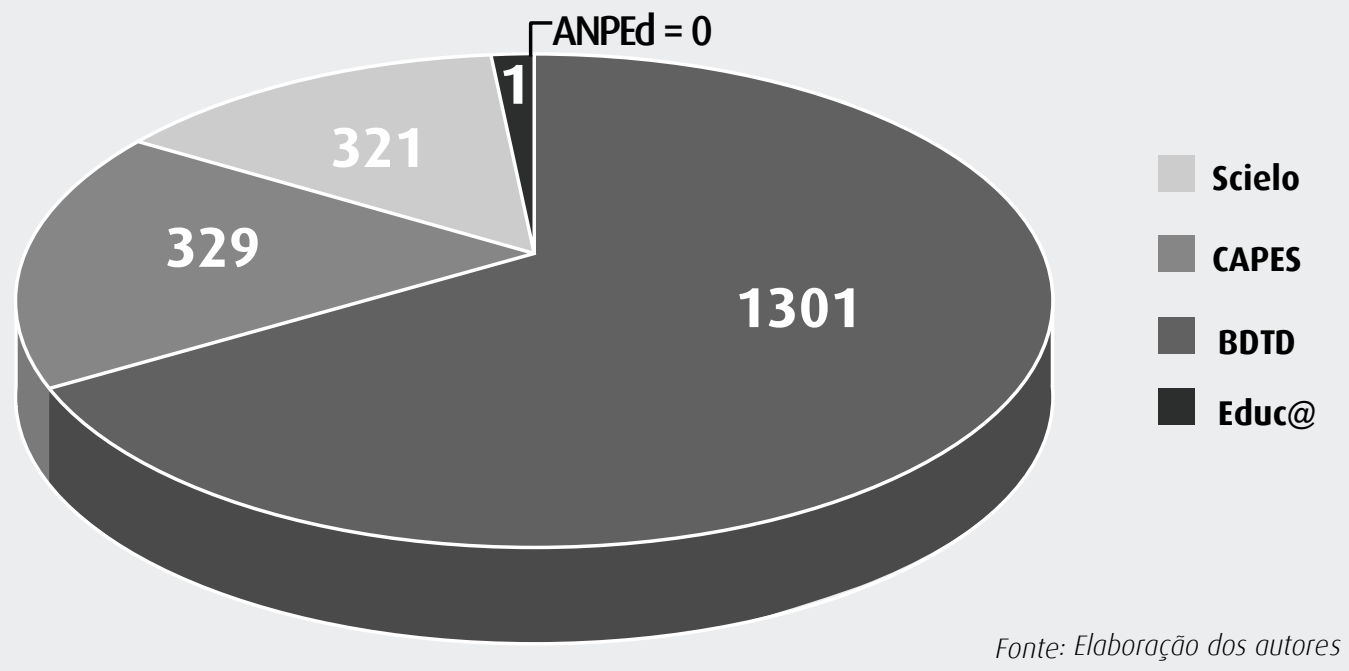

Tanto o PROERD quanto o PROEIS estabelecem a participaçáo direta de policiais militares fardados, em serviço, nos contextos escolares, ainda que em parte das unidades escolares, escolhidas de acordo com os propósitos da gestáo estadual. No caso do Rio de Janeiro, ambos os programas são aplicados, com objetivos diferentes. O PROEIS é voltado para segurança das instalaçóes e das relaçóes entre os usuários do sistema estadual de ensino e o PROERD desenvolve atividades educativas a respeito dos prejuízos do uso de drogas.

Além disso, questôes vinculadas à segurança pública afetam diretamente a vida de toda comunidade escolar de tal forma que demandaram a implantaçáo desses programas. No entanto, o silêncio da ANPEd a respeito do tema nos leva à reflexáo das motivaçóes para tal ausência, contudo, não é propósito nosso aqui dar conta de tais questóes. Trazemo-las à tona apenas para expressar nossa estranheza diante da ausência desse debate no principal espaço de interlocuçáo científica da área de educaçáo.
Voltando ao Gráfico 1, observamos que o banco de teses e dissertaçóes do IBICT apresentou um número muito superior às demais bases de dados, contudo, muitas foram pesquisas repetidas, tanto em palavras-chave diferentes, quanto na mesma palavra-chave, de modo que aconteceu de uma única pesquisa aparecer em multiplicidade. Observamos ainda, que muitas dessas pesquisas sobre segurança pública utilizaram mais de uma das palavras-chave elencadas por nós, o que fatalmente, aumentou numericamente a amostra. Assim, após a filtragem de todas as repetiçóes de todas as bases de dados, a amostra foi reduzida ao número total de 1.215 pesquisas, distribuídas pelas categorias adotadas, de acordo com o gráfico 2 .

Contudo, a amostra ainda apresentava distorçáo, dado o número elevado de pesquisas que surgiram na filtragem pelas palavras-chave, mas foram consideradas "não pertinentes" em relaçáo à área de segurança pública. Desse modo, ao aplicar novo filtro, permaneceram 775 pesquisas, que não necessariamente abordam o objeto "polícia militar", principalmente no que diz respeito 
à palavra-chave "segurança pública", abrangendo também as demais instituiçóes que a compóem, como Polícia Civil, Corpo de Bombeiros, Sistema Penitenciário etc.

\section{Gráfico 2 - Número de trabalhos científicos levantados por fonte (2015)}

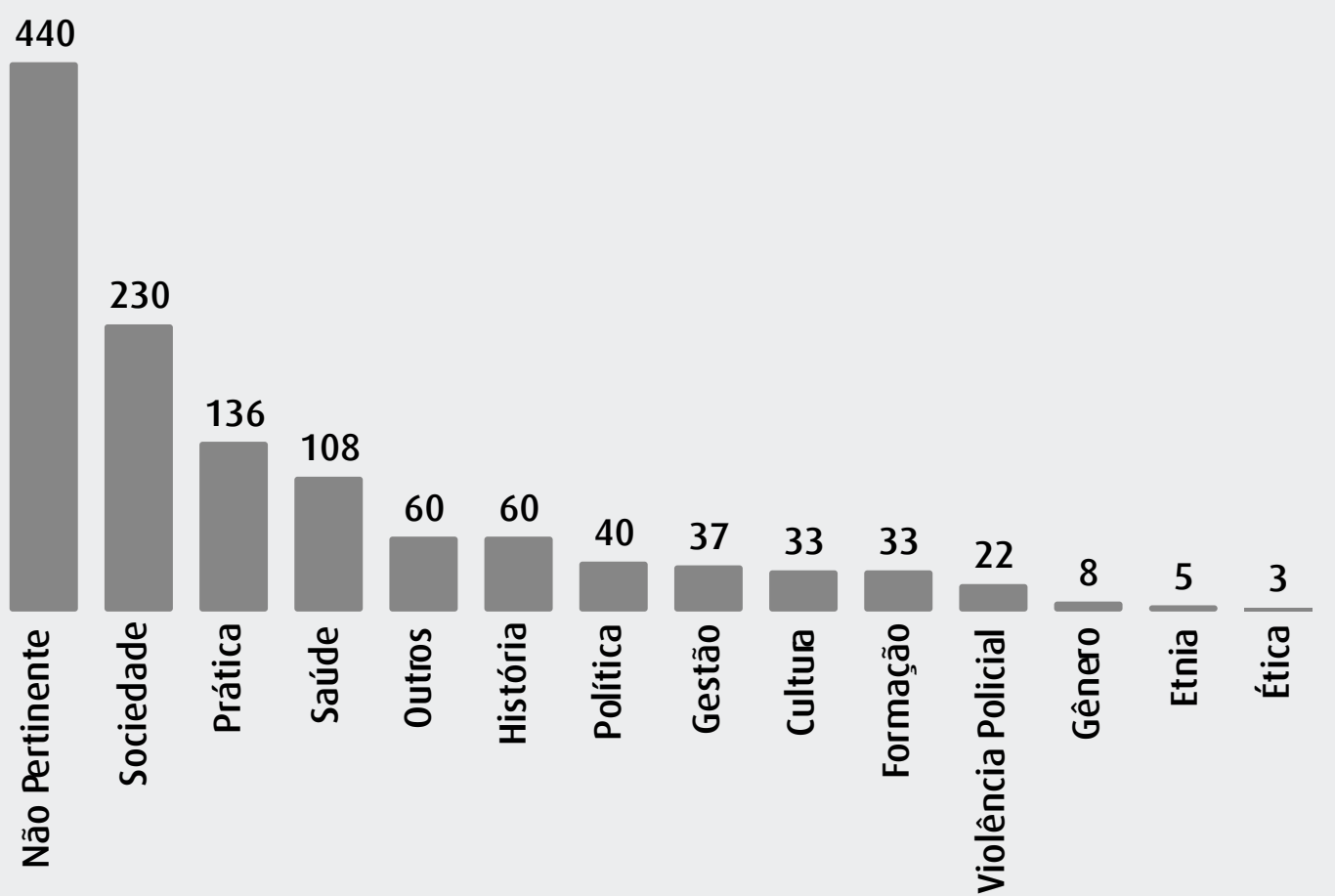

Fonte: Elaboraçõo dos autores

Considerando, que a palavra-chave "segurança pública” apresentou maior quantitativo de incidências, além do eixo "outros", utilizado para classificar abordagens a temáticas diversas que não puderam ser encaixadas nos demais eixos, pudemos perceber que as pesquisas que efetivamente abordaram apenas a instituiçáo Polícia Militar compreendem um universo de 468 trabalhos, conforme distribuídas pelas palavras-chave no Gráfico 3.

Em relaçáo ao objeto dessas pesquisas, mais de $20 \%$ do total abordam a saúde do Policial Militar; 16\% abordam a perspectiva da prática na atuaçáo do Policial Militar; 15\% abordam a relaçáo entre sociedade e Polícia Militar; pouco mais de $10 \%$ abordam uma narrativa histórica das instituiçôes policiais militares. Dentre os trabalhos restantes, a formaçáo policial militar abarca cerca de $8 \%$ do total das pesquisas encontradas. A amostra encontrada sobre formaçáo policial militar nas bases de dados compreende um total de 43 trabalhos: artigos (12), dissertaçóes (23) e teses (8) $)^{5}$. 


\section{Gráfico 3 - Número de trabalhos científicos levantados \\ por palavra chave (2015)}

\section{4}

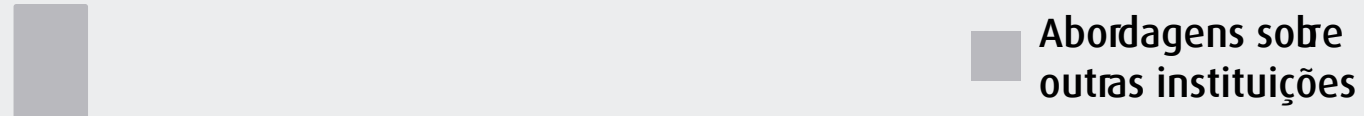

173

17

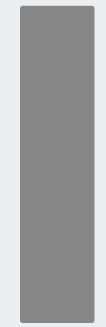

109

葛

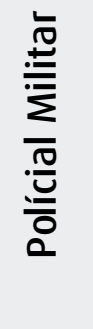
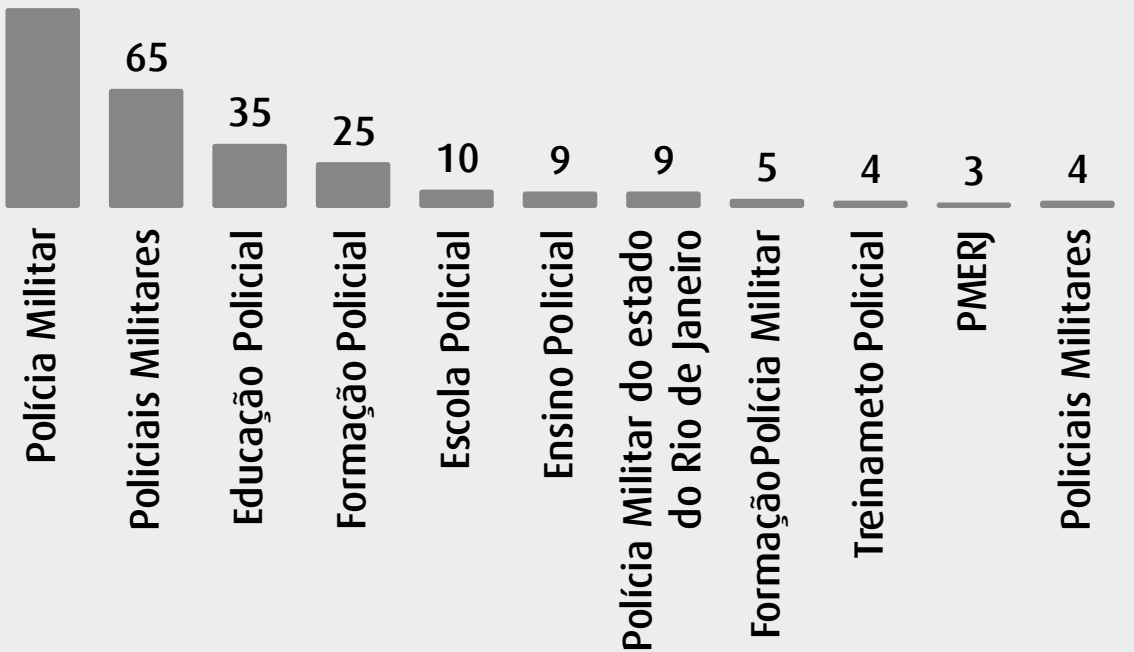

Fonte: Elaboroção dos autores

O ano de 2012 apresentou um pico na produção de pesquisas sobre a formação policial militar. Tal fato foi resultado da ampliaçáo do debate sobre a segurança pública no país. A partir do ano 2000, o projeto Segurança Cidadá desenvolvido pela ONU, noâmbito do Programa das Naçóes Unidas para o Desenvolvimento (PNUD) fomentou acordos de cooperaçáo técnica para o Brasil (ONU, 2009). Diversas açóes na área de segurança pública foram desenvolvidas no Brasil para profusão da concepçáo de segurança cidadá por meio do acordo de cooperaçáo técnica BRA/04/029-Segurança Cidadá. Na área da educaçáo profissional em segurança pública, a implementaçáo da $\mathrm{MCN}$, a criaçáo da Rede de AltosEstudos em Segurança Pública (RENAESP) ${ }^{6}$, o Projeto Pensando Segurança Pública - todos no âmbito da SENASP - proporcionaram

disponíveis nos bancos de dados consultados, impossibilitando nosso acesso ao material completo.

6 A RENAESP foi criada em 2005, no âmbito da SENASP, com o objetivo de proporcionar formação dos profissionais de seguranço

pública, a partir de parcerias do Ministério da Justiça com Instituiçães de Educação Superior (IES) do país.

7 Foram abertos editais para projetos de pesquisas financiados pelo Ministério da Justiça para o desenvolvimento de pesquisas na áreo de segurança pública. O resultado dos editais deu origem à Coleção Pensando Segurança Pública, em três volumes, disponíveis no Biblioteco Digital do Planejomento. 
o fomento ao debate acerca da segurança pública no país. Nesse sentido, as novas propostas para segurança pública parecem ter influenciado a realizaçáo de pesquisas sobre o tema formaçáo policial militar no período. Dispusemos no Gráfico 4 a seguir, a evoluçáa de produçáo de pesquisas científicas sobre o tema no período investigado. lhos), Rio de Janeiro (3 trabalhos), Minas Gerais (3 trabalhos), Paraná (3 trabalhos), Rio Grande do Norte (3 trabalhos), Ceará (2 trabalhos), Maranhão (1 trabalho), Mato Grosso (1 trabalho), Piauí (1 trabalho), Pará (1 trabalho), Bahia (1 trabalho), Alagoas (1 trabalho) e Pernambuco (1 trabalho).
Tais pesquisas foram realizadas em escolas de formaçáo das polícias militares dos estados de São Paulo (7 trabalhos), Paraiba (6 trabalhos), Goiás (5 trabalhos), Rio Grande do Sul (4 traba-
A análise do vínculo dos autores das pesquisas sobre formação policial militar com as polícias militares pode esclarecer o interesse sobre o tema. Distinguimos os trabalhos publicados de autoria

\section{Gráfico 4 - Evolucão anual do número de trabalhos científicos levantados sobre formação policial militar (2015)}

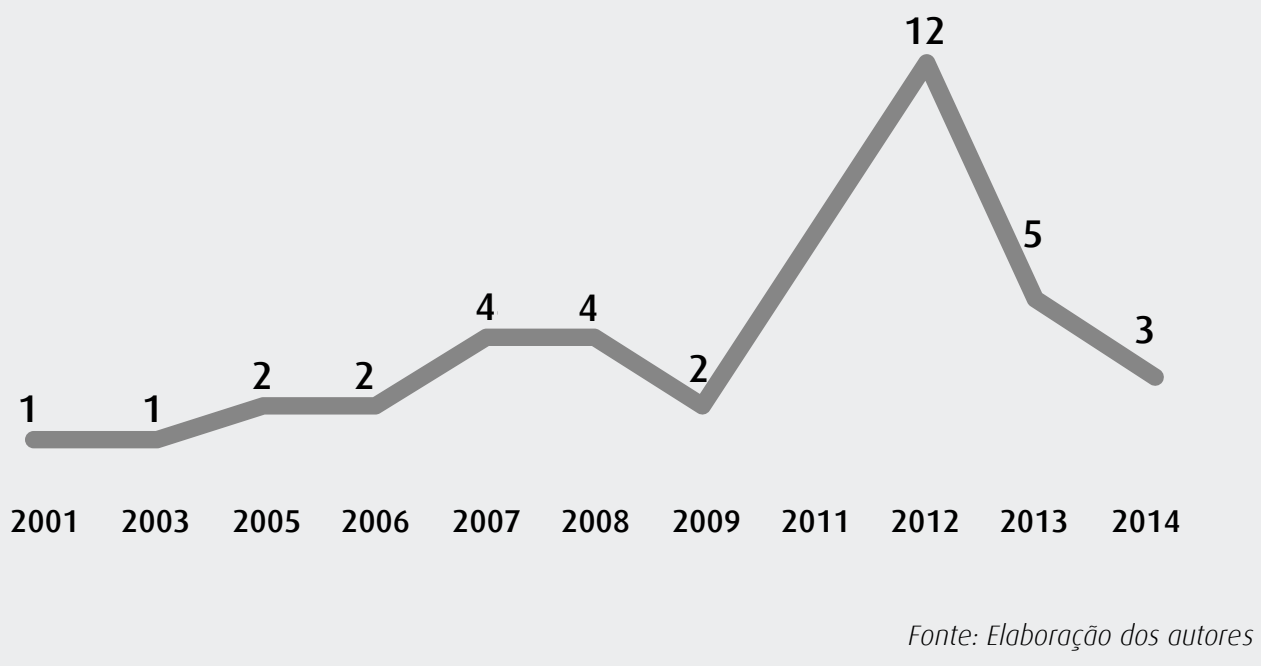

de pesquisadores acadêmicos daqueles de auto- raçáo ria de policiais militares, conforme apresentamos no Gráfico 5, onde discriminamos os trabalhos, segundo categoria de autor, por estado da fede-

Um ponto que merece atençáo sobre a autoria dessas pesquisas é que mais de $58 \%$ dos

8 Como os trabalhos que compõem nosso objeto de onálise sõo aqueles disponiveis em bancos de dados cientificos, ficaram de fora 8 Como os trabalhos que compõem nosso objeto de análise são aqueles disponíveis em bancos de dados cientificos, ficaram de fora os trabalhos produzidos internamente nas corporações policiais militares, as quais acreditamos possuir vasto acervo sobre o tema. No caso específico do estado do Rio de Janeiro, por exemplo, a produção de artigo científico na órea de segurança pública é um requisito parcial para condusão de alguns cursos. Isso ocorre no Curso de Formação de Oficiais (CFO), dirigido a alunos da Academia de Polícia Militar (APM); no Curso de Aperfeiçoamento de Oficiais (CAO), direcionado a copitães e no Curso Superior de Polício (CSP), direcionado a oficiais superiores da PMERJ. Entretanto, como se trato de acervo interno da instituição, não tivemos acesso a esta produç̧ão. Mas é inegóvel que seriam relevantes estudos posteriores para levantar nesse acervo o que há produzido sobre a formação policial militar. 
seus autores sáo policiais pertencentes às polícias militares das unidades federativas onde foram realizadas as pesquisas e $42 \%$ das pesquisas foram realizadas por pessoas que não pertencem aos quadros da segurança pública. $\mathrm{O}$ fato de que a maioria da produçáa científica sobre formaçáa policial militar ter sido realizada pelos próprios policiais militares denota a necessidade institucional de produçáo de conhecimento acerca da temática. Por outro lado, esses dados também

\section{Gráfico 5 - Número de trabalhos científicos levantados sobre formação policial militar por estado da federação e categoria de autor (2015)}

Pesquisador

Policial

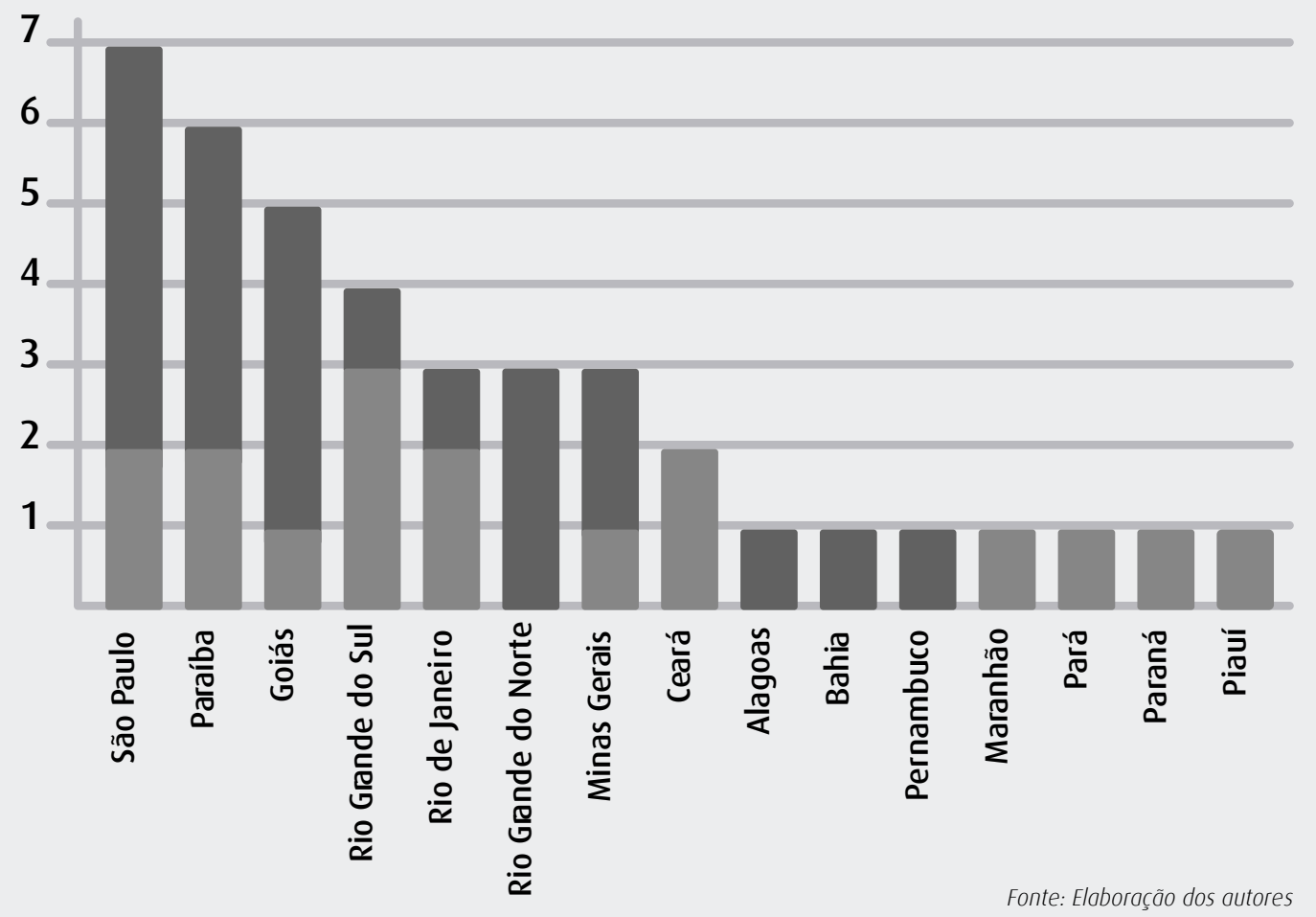

podem demonstrar o baixo envolvimento da sociedade, principalmente do meio acadêmico, com a questáo da formaçáo policial militar e com seu impacto na segurança pública em todo o país. Os fatores que corroboram com essa realidade podem estar atrelados ao estágio atual - ainda incipiente - de consolidaçáo da democracia brasileira (Cf:: PINHEIRO; SADER, 1985; KANT DE LIMA, 1999; MUNIZ, 2001; LIMA; RATTON; AZEVEDO, 2014; PONCIONI, 2012), bem como à dificuldade de abertura das instituiçóes policiais do país para o diálogo com o conjunto da sociedade. No en- tanto, tais barreiras precisam ser desconstruídas para que haja avanços nos resultados obtidos, principalmente no que diz respeito à necessidade de atuaçáo policial numa perspectiva cidadá. Nesse sentido, é possível notar certo avanço em alguns estados brasileiros no que se refere ao desenvolvimento de pesquisas relacionadas à segurança pública. Esses avanços seguem na direção de uma concepçáo de segurança pública mais afinada com os avanços democráticos da sociedade. Esta percepçáo também se expressa a partir da produçáo bibliográfica da área de formaçáo profissional, apesar de ainda estar longe do ideal. 
É importante ressaltar que os estados do Rio Grande do Sul e Rio de Janeiro são aqueles onde há mais pesquisadores envolvidos em estudos sobre o tema. $\mathrm{O}$ interesse da academia pelo tema formaçáo policial militar pode fornecer pistas sobre as demandas presentes na própria sociedade. No caso do estado do Rio de Janeiro, podemos apontar a existência de alguns organismos de pesquisa que desenvolvem trabalhos científicos na área de segurança pública nas principais universidades públicas, como por exemplo: o Instituto de Estudos Comparados em Administraçáo Institucional de Conflitos (INCT/INEAC), vinculado à Universidade Federal Fluminense (UFF); o Núcleo de Estudos da Cidadania e Violência Urbana (NUCVU), vinculado à Universidade Federal do Rio de Janeiro (UFRJ); e o Laboratório de Análise da Violência (LAV), vinculado à Universidade do Estado do Rio de Janeiro (UERJ). Apesar disto, ainda é pequeno o número de pesquisas desenvolvidas sobre a formaçáo policial neste estado da federaçáo. Por outro lado, em algumas unidades federativas do Brasil o tema tem despertado interesse apenas de policiais militares ou apenas de pesquisadores. Tanto em um caso, como noutro o vínculo do autor da pesquisa com o tema pode demonstrar o envolvimento da academia com o tema.

Por outro lado, notamos neste levantamento, que poucos policiais militares do estado do Rio de Janeiro realizaram pesquisas sobre a formaçáo policial no âmbito das universidades, de modo que não se pode precisar se isto se deve ao fato de existirem poucos policiais buscando especializaçáo no nível de pós-graduaçáo ou se, quando procuram esse tipo de formaçáo, interessam-se mais em pesquisar sobre outras questóes alheias à sua profissáo.
Nesse quesito, o estado de São Paulo, Paraiba e Goiás sáo aqueles em que os policiais militares demonstram buscar especializaçáo em nível de pós-graduaçáa, produzindo pesquisas e, consequentemente, disponibilizando sua produçáo científica à sociedade. Tal fato, provavelmente, está atrelado ao modelo do sistema de ensino para formaçáo profissional na área de segurança pública utilizado por esses estados da federaçáo.

Outro dado relevante obtido a partir dos dados levantados se refere a categoria dos sujeitos investigados. Dentre as pesquisas encontradas, 18 não fazem distinçáo entre oficiais e praças; 01 engloba todos os profissionais de segurança pública, tratando de militares e de civis, conforme mostramos no Gráfico 6. Somando essas duas categorias, teremos o total de 19 trabalhos (45\%). Quanto aos 24 trabalhos restantes (55\%), o número de pesquisas realizadas com oficiais das polícias militares é o dobro das pesquisas com praças, apesar de dessas instituiçôes serem compostas por maioria de praças. No caso do estado do Rio de Janeiro, os praças representam 93\% da PMERJ'.

Observamos que nenhuma tese de doutorado levantada tem como populaçáo investigada um conjunto de sujeitos formado exclusivamente de praças das polícias militares. Por outro lado, 05 teses são resultantes de pesquisas nos cursos de formaçáo de oficiais das polícias militares.

Conforme observam Caruso, Moraes e Pinto (2010) a formação de praças e de oficiais são distintas:

Outra avaliação realizada por ambos os segmentos aponta, ao longo da formaçáa, um profundo

9 Nas polícios militares os oficiais são aqueles que exercem cargos de gestõo e comando, organizados pelas seguintes patentes: $2^{\circ}$ tenente, $1^{\circ}$ tenente, capitõo, major, tenente coronel e coronel, em ordem crescente hierarquicamente. Os praças são responsóveis pela execução e estão organizadas pelas seguintes graduações: soldado, cabo, $3^{\circ}$ sargento, $2^{\circ}$ sargento, $1^{\circ}$ sargento e subtenente. 
afastamento entre os alunos oficiais e os alunos praças. Não está estruturada formalmente nenhuma perspectiva de aproximaçáo destes dois mundos, somente a referência distante de que um dia, uns estarão comandando e outros obedecendo. Neste sentido, ambos os ciclos configuram-se essencialmente em mundos de formaçáo paralelos e, como tal, nunca se comunicam; todavia, no momento em que estáo prestes a atuar numa unidade operacional, se encontram diante do fato de terem necessariamente que trabalharem jun- tos, sem ao menos compreenderem claramente a "natureza da missão" de cada um (CARUSO; MORAES; PINTO, 2010, p. 113).

Contudo, a distinçáo entre a formação de oficiais e praças das polícias militares parece menos perceptível para os pesquisadores civis que para os pesquisadores militares. Se estabelecermos uma relação entre o número de teses e dissertaçóes produzidas por pesquisadores civis que tratam da instituiçáo como um todo e o número

\section{Gráfico 6 - Número de trabalhos científicos levantados sobre formação policial militar por categoria de sujeitos investigados e nível de comunicação científica (2015)}

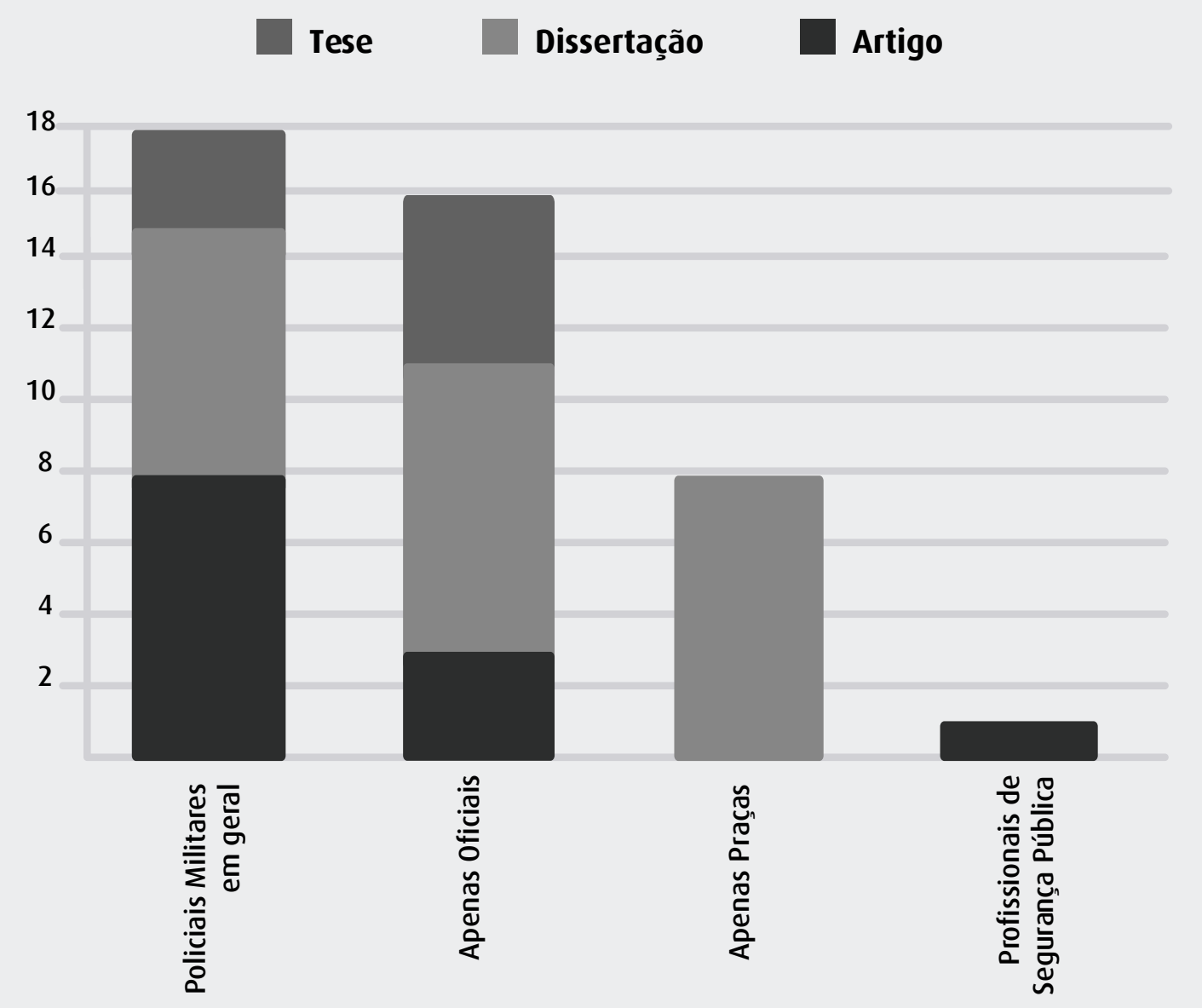


das que fizeram distinção de círculo hierárquico (praças e oficiais), perceberemos que os trabalhos que se inserem na primeira categoria são o dobro daqueles pertinentes à segunda categoria.

Por outro lado, quando se observa o conjunto de teses e dissertaçóes produzidas por oficiais das polícias militares sobre a formação profissional de suas instituiçóes, percebe-se que aquelas que têm como objeto de estudo o curso de formação de oficiais são quase o dobro daquelas que têm como objeto de estudo o curso de formaçáo de praças. Chama-nos a atenção o fato de não termos levantado nenhuma tese ou dissertaçáo realizada por praça dessas instituiçóes. Obviamente, isto significa que não existem praças que tenham concluído cursos de pós-graduaçáo stricto sensu. No máximo poderíamos afirmar que a formaçáo do policial militar não tem sido tema de pesquisa dessa populaçáo, uma vez que em pesquisa realizada com profissionais de segurança pública de todo o pás, foi aferido que cerca de 39\% desses profissionais têm nível superior completo e mais de $27 \%$ fizeram algum curso de especializaçáo, mestrado ou doutorado (LIMA; BUENO; SANTOS, 2014, p. 9).

Durante a análise do material coletado, observamos ainda, que dentre os 31 teses e dissertaçôes encontradas sobre formaçáo policial militar apenas 12 foram desenvolvidas em programas de pós-graduaçáo em Educaçáo. Os 19 restantes foram produzidos por pesquisadores da Sociologia, da Administraçáo, das Ciências Jurídicas, da Psicologia e da História. Fato que corrobora a multiplicidade de perspectivas a partir das quais a formaçáo policial militar pode ser pesquisada, enriquecendo a abordagem ao tema. Contudo, por outro lado, demonstra menor envolvimento de pesquisadores da área da educaçáo com a educação profissional em segurança pública.

\section{Abordagem Temática da Produção}

A concepção de segurança cidadã está fundamentada na mediaçáo entre coerção e consenso em detrimento da concepçáo tradicional de segurança pública fundamentada na coerçáo. A nova concepçáo aponta para gestáo de conflitos, para tanto, o policial que atua na execuçáo da política torna-se uma espécie de prestador de serviço de segurança pública. Nesse contexto, a profissionalizaçáo do policial é um elemento preponderante para aplicaçáo da nova concepçáo, portanto, o desenvolvimento de políticas para formaçáo policial ganha vulto no debate sobre segurança pública no país (CF:: ALBUQUERQUE, 2001; PONCIONI, 2005; 2007; CARUSO; MORAES; PINTO, 2006; PEREIRA; CAMPOS, 2009; 2013; POLICARPO JR, 2012; SILVA, J. 2012). A análise dos temas presentes na amostra coletada confirma isso.

Uma análise preliminar da literatura que compóe nossa amostra sobre formaçáo policial militar nos permite afirmar que mais de 50\% das pesquisas dizem respeito ao currículo utilizado na formaçáo de policiais militares. Esse número expressivo de pesquisa sobre o tema em questáo está relacionado ao fato de, em 2009, ter sido implementada a Matriz Curricular Nacional para formaçáa dos profissionais de segurança pública (BRASIL, 2009). Isto despertou $\mathrm{o}$ interesse de pesquisadores de vários estados $\mathrm{da}$ federaçáo em avaliar a aplicaçáo do Documento pelas escolas de formaçáo de policiais militares, sobretudo o impacto da inserçáo da disciplina "Direitos Humanos" na formaçáo policial militar. Essa disciplina, inclusive, conta com previsáo de carga horária expressiva na matriz curricular nacional (BRASIL, 2009) pelo entendimento da importância da massificaçáo do tema nas academias de polícia, conforme apontado por Luiz (2003; 2008), Cerqueira (2006), Basílio (2007), Silva, S. (2007), Blasius (2008), Silva, J. (2009), Lopes (2011), Cerqueira (2011), Pereira Jr. (2012), Pereira (2012), Ferreira (2012), Nas- 
cimento (2013), Cruz (2013), Karpinski (2013) eSantos (2014).

Entendemos que a inserção e a "fiscalizaçáo" da aplicaçáo do currículo implementado por meio da pesquisa acadêmica demonstra a influência subjetiva da nova concepçáo de segurança pública nessas pesquisas. Nesse caso, o currículo desenvolvido torna-se instrumento para medir a implementaçáo da política de segurança, por mais que esse não seja o objetivo da pesquisa $\mathrm{e}$ sequer o pesquisador tenha isso em mente. $\mathrm{O}$ movimento político que propóe a nova concepção atua pedagogicamente para formaçáo de hegemonia política capaz de interferir objetiva e subjetivamente no debate sobre o tema.

Por outro lado, a disciplina "Direitos Humanos" ainda abarca outro tema muito presente nas pesquisas encontradas: a formaçáo cidadá do policial militar. Esse tema é fruto do entendimento da necessidade de uma nova formaçáo paral na polícia militar, de modo que esta se adeque às exigências de um Estado Democrático de Direito por meio de uma formaçáo militar humanizadora que capacite o policial militar para a gestáo de conflitos e prestaçáo de serviço de segurança pública pautado no respeito aos Direitos Humanos. Tal perspectiva está presente nas pesquisas de Brito (2005), Jacondino (2011), Miranda (2011), Leal (2011), Souza (2012), França (2012 A), Santos (2012), Silva, J. (2012), Silva, A. (2012), França (2012 B), Pereira e Policarpo Jr. (2012), Barboza (2013) e Campos (2009; 2013).

Por fim, o terceiro tema recorrente nas pesquisas diz respeito à formaçáa policial militar frente à sua prática cotidiana, buscando avaliar a coerência da relaçáo entre o conteúdo curricular presente na escola de formaçáo do policial mi- litar e sua pertinência para prestaçáo de serviço de segurança pública à sociedade. Isto se observa nas pesquisas de Albuquerque (2001), Caruso (2004), Poncioni (2005; 2007), Silva, J. (2009) Rudinicki (2007), Silva, R. (2009), Kruger (2011), Lima (2011), Silva, R. (2012) e Brunetta (2012).

Em suma, com base na literatura levantada, nossa análise aponta para três temas mais recorrentes no conjunto de trabalhos, são eles: 1) a necessidade de uma formaçáo humanizadora; 2) uma formaçáo pautada na ampla abordagem ao conteúdo de Direitos Humanos; 3) a relaçáo entre a formaçáo e a prática do policial militar na prestaçáo de serviço. Constata-se ainda que vários desses trabalhos perpassam os três temas mencionados, ainda que não os trate como ponto central do trabalho. $\mathrm{O}$ fato de que os principais temas presentes nas pesquisas tomam como fundamento a perspectiva de Segurança Cidadá demonstra a influência e a abrangência da nova concepçáo de segurança pública. Praticamente todas as pesquisas desenvolvidas no período que compreende nosso recorte histórico tomam como objeto algum elemento ou a perspectiva de Segurança Cidadá ${ }^{10}$ como um todo.

O quadro analítico estruturado para observar os vínculos entre as pesquisas nos permitiu delinear alguns pontos coincidentes nas conclusóes dessas pesquisas. Lopes (2011) concluiu, ao avaliar o Curso de Formaçáo de Oficiais (CFO) no estado de Minas Gerais, que há impedimentos para a efetivaçáo prática da concepçáo pedagógica estabelecida teoricamente, dentre eles, a cultura militar. Ademais, a constataçáo de uma formaçáo tradicional, impregnada por um currículo oculto que resiste às tentativas de mudanças foi apontada por Luiz (2003), Blasius (2008), Karpinski (2013), Silva, J. (2009), Silva, 
R. (2012) e também por Cruz (2013), quando se refere a este currículo oculto como "contra currículo”. Essas pesquisas se concentram no Ceará, São Paulo, Paraná, Rio Grande do Norte e Bahia.

Para Santos (2012), Lopes (2011), Barbosa (2013), Rudnicki (2007), Silva, J. (2009) e Basílio (2007) há pouca evidência de mudanças nas polícias militares do Maranhão, Minas Gerais, Paraba, Rio Grande do Sul Rio Grande do Norte e Rio de Janeiro. Por outro lado, a formaçáo do policial militar, de acordo com Leal (2011), é vista como um dos instrumentos de mudança cultural nessas instituiçōes que, consoante com Jacondino (2011), Lima (2011) e Karpinski (2013), deve formar perfil e identidade profissional adequada aos contextos atuais, principalmente sob o viés humanizador, conforme defendem Luiz (2003), Cerqueira (2011), Leal (2011) e Miranda (2011).

Outro ponto de tensáo diz respeito à definiçáo do papel atribuído aos órgáos de segurança pública entre a funçáo de Segurança Pública e de Segurança Nacional, conforme bem abordado por Silva J. (2009) e Pereira (2012). Segundo Brunetta (2012), para formaçáo de policiais militares no estado de São Paulo prevalece a ideia de controle social, que representa um conceito tradicional de segurança pública que, segundo Kruger (2011), é desconhecido pela sociedade. Tal conceito corrobora tanto o ideal militarista, quanto a formaçáo jurista que, para Silva J. (2009), representam dois grandes mitos na formaçáo para o trabalho do policial militar.
Os apontamentos encontrados nessas pesquisas denotam a mesma tensão entre as concepçóes de segurança pública que Muniz (2001, p. 187) já mencionava anteriormente:

[...] o ensino do Direito Penal nas Academias da Polícia Militar tornou-se uma tradiçáo nas duas últimas décadas. As disciplinas da área jurídica passaram a ocupar uma parte táo expressiva da formação policial que os oficiais PMs saem habilitados a concluírem o bacharelado em Direito em, no máximo, dois anos. Além de não recobrir o conteúdo interdisciplinar necessário ao profissional de polícia ostensiva, uma formação policial voltada, quase que exdusivamente, para as ciências jurídicas, parece ter contribuído para o reforço de uma visão criminalizante da ordem pública, extremamente danosa aos serviços ostensivos de polícia. A criminalização do mundo social é correlata a uma espécie de legalismo moral, cujos efeitos perversos em termos de açáo cotidiana de polícia são, na maior parte dos casos, irreparáveis.

Lopes (2011), Santos (2012) e Rudnicki (2007) defendem a reestruturaçáo da formaçáo dos policiais militares que, para Cerqueira (2011) e Santos (2014), deve estar adequada ao regime democrático, portanto, voltada para a resoluçáo de conflitos sociais, conforme apontam Miranda (2011), Brito (2005), Silva R. (2012), Pereira (2012) e Luiz (2003). Já para Luiz (2008) e Brito (2005), não basta apenas a reestruturaçáo da formaçáo inicial do policial militar, mas há ainda a necessidade de que essa formaçáo seja perma-

de dois modelos: o de policiamento orientado paro gestão de conflitos e o de policiamento comunitário. A partir desso formulação, "Entende-se a Segurança cidadã como um modelo que tem por finalidade expandir o processo de articulação de todas as forças da sociedade e formas de governo no combate à criminalidade. De tal modo, cada representante dessas diferentes forças seria co-responsóvel por planejar e controlar as operações em cado âmbito que se deseja intervir, observando as características locais, bem como desenvolver técnicos de prevenção, mediação, negociação e investigação de conflitos sociais e de crimes" (INSTITUTO SÃO PAULO CONTRA A VIOLÊNCIA, 2012). 
nente e continuada. Justamente por sua importância, a qualificação deve figurar como um dos principais focos para as instituiçóes policiais militares, conforme ressaltado por Lopes (2011), Luiz (2008), Miranda (2011) e Blasius (2008).

\section{À Guisa de Conclusão}

A proposta de mudanças na formaçáo policial militar, a partir de açóes políticas da ONU, que culminaram no desenvolvimento de um aurrículo nacional no Brasil tem relaçáo direta com a produçáo científica sobre a formaçáo policial militar. Podemos afirmar que a difusáo do conceito de Segurança Cidadá fomentou certo avanço na produçáo científica e o debate sobre o tema. Contudo, conduímos que o número de produçáo acadêmica a respeito da formaçáo do policial militar ainda é tímida. Além disto, estudos mais aprofundados sobre a realidade da formaçáo de policiais militares se fazem necessários, devido à superficialidade que predomina no senso comum, quando se trata de segurança pública e violência. Esses estudos também podem contribuir consideravelmente para a superaçáo da visão reacionária da política de segurança pública pautada no combate ao inimigo que, na maioria das vezes, identifica como seu inimigo os pobres, os negros, os moradores de comunidades (Cf.: VEIGA; SOUZA, 2016).

É evidente que a formaçáo do policial militar se insere na política de segurança pública, mas é preciso compreendê-la no conjunto dessa política, considerando-se todos os elementos sociais, políticos e econômicos que interferem em seu desenvolvimento. É preciso também considerar as contradiçóes que perpassam o desenvolvimento das políticas públicas como um todo, para se ter uma visáo mais concreta da política de segurança pública e, mais especificamente, da formaçáo do policial militar. Mas uma análise da literatura levantada sobre o tema náo nos oferece boas perspectivas nesse sentido.

A literatura levantada que trata da formaçáo do policial militar apresenta predominância de abordagens que tem como objeto de análise a questáo da adaptaçáo das instituiçóes de segurança pública às novas exigências do Estado de direito, com observância aos Direitos Humanos. Vale destacar que essa nossa avaliaçáo não se pauta simplesmente no aspecto quantitativo, mas também no aspecto qualitativo. O que queremos apontar é que essa abordagem não só é a mais recorrente na literatura sobre o tema, como também é a abordagem com maior potencial analítico, uma vez que apresenta análises que váo além da percepçáo imediata da realidade, demonstrando habilidade para considerar a política de segurança pública como um fenômeno social de interesse público e não simplesmente como uma questáo militar de combate ao crime.

Por fim, uma última constataçáo que nos chama a atençáo é que o estado do Rio de Janeiro, onde é clara a política de combate ao inimigo - evidenciada nos altos índices de letalidade policial e letalidade de policiais - é também um dos estados que apresenta tímida produçáo de conhecimento sobre a formaçáo policial militar. O desenvolvimento de uma concepçáo de segurança cidadá, nesse sentido, torna-se campo de disputas político-ideológicas. Portanto, a produçáo de conhecimento acerca formaçáo policial militar nesse estado da federaçáo não só é pertinente, mas necessária. 


\section{Referências Bibliográficas}

ALBUQUERQUE, Carlos Linhares de; MACHADO, Eduardo Paes. Sob o signo de marte: modernização, ensino e ritos da instituição policial militar. Sociologias, Porto Alegre, ano 3, n 5, jan/jun 2001, p.214-237, 2001.

BARBOZA, Miriane da Silva Santos. Educação em direitos humanos em uma instituição militar. 271 p. Tese de Doutorado em Psicologia Social - Universidade Federal da Paraíba (UFPB), 2013.

BASÍlIO, Márcio Pereira. 0 desafio da formação do policial militar do estado do Rio de Janeiro: utopia ou realidade possível? 216 p. Dissertação de Mestrado em Administração - Fundação Getúlio Vargas (FGV) Rio de Janeiro, 2007.

BITTNER, Egon. Aspectos do trabalho policial. Tradução: Ana Luísa Amêndola Pinheiro. Série: Polícia e Sociedade, Vol. 8, Núcleo de Estudos da Violência da Universidade de São Paulo (NEV/USP). São Paulo: Edusp, 2003. 385 p.

BLASIUS, LUciano. A resiliência na formação do policial militar. 85 p. Dissertação de Mestrado em Educação - Universidade Federal do Paraná (UFPR), 2008.

BRASIL. SENASP (2009). Ministério da Justiça - Secretaria Nacional de segurança pública. Matriz Curricular Nacional Para Ações Formativas dos Profissionais da Área de segurança pública. Brasília, DF, 2009d.

IPEA (2012). Sistema de Indicadores de Percepção Social (SIPS) (2012). Pesquisa IPEA, Brasília, DF, 2012. Disponível em: <http://www. ipea.gov.br/portal/index.php?option=com_content\&view=articlecid=24439>. Acesso em: 02 mai. 2015

BRITO, Francisco de Assis Toscano. Direitos humanos e cidadania em foco: percepções sobre a formação do policial militar da Paraíba. 101 p. Dissertação de Mestrado em Serviço Social - Universidade Federal da Paraíba (UFPB), 2005.
BRUNETTA, Antônio Alberto. Reforma intelectual da Policia Militar. 150 p. Tese de Doutorado em Sociologia - Universidade do Estado de São Paulo (UNESP), 2012.

CAMPOS, Alexandre Flexa. A educação andragógica e a instrução operacional na polícia brasileira. REBESP, Goiânia, vol. 1, n² 2, p. 13-15, Jan-Jul, 2009.

Qualificação das polícias militares no brasil: entre uma polícia essencialmente militar e uma polícia militar como modelo de instituição de segurança pública democrática para os dias atuais. REBESP, Goiânia, v. 5, п. 1, p. 63-68, Jan-jul. 2013.

CARUSO, Haydée Glória CrUz. Das práticas e dos seus saberes: a construção do "fazer policial" entre as praças da PMERJ. 188 p. Dissertação de Mestrado em Antropologia - Universidade Federal Fluminense (UFF), 2004.

; MORAES, Luciane Patrício Braga de; PINTO, Nalayne Mendonça. Polícia Militar do Estado do Rio de Janeiro: da escola de formação à prática policial. SENASP/ANPOCS: Segurança, Justiça e Cidadania - Pesquisas aplicadas em segurança pública, Brasília, n.04, ano II, p.101-118, 2010.

CERQUEIRA, Homero De Giorge. A disciplina militar em sala de aula: a relação pedagógica em uma instituição formadora de oficiais da Polícia Militar do estado de São Paulo. 230 p. Dissertação de Mestrado em Educação - Pontífice Universidade Católica (PUC) de São Paulo, 2006.

Os paradoxos do currículo da academia de polícia militar do Barro Branco: a cidadania como fundamento das forças de segurança pública. [S. I.] p. Tese de Doutorado em Educação - Pontífice Universidade Católica (PUC) de São Paulo, 2011. 
CNI-IBOPE (Pesquisa). Retratos da sociedade brasileira: problemas e prioridades do Brasil para 2014. Brasilia: CNI, 2014. 44 p. Disponível em: <http:// www.fiemt.com.br/arquivos/1420_12_02_problemas_e_prioridades_para_2014.pdf>. Acesso em: 02 mai. 2015

CRUZ, Lara Abreu. Currículo e contra-currículo: uma análise da formação profissional dos soldados do ronda do quarteirão. 155 p. Dissertação de Mestrado em Políticas Públicas e Sociedade-Universidade Federal do Ceará (UFCE), 2013.

FERREIRA, Deyvid Braga. 0 signo? segurança pública? Na matriz curricular unificada da SENASP: condições de produção e efeitos de sentido. 125 p. Dissertação de Mestrado em Educação - Universidade Federal de Alagoas (UFAL), 2012.

FRANÇA, Fábio Gomes de. Disciplinamento e humanização: a formação policial militar e os novos paradigmas educacionais de controle e vigilância. 163 p. Dissertação de Mestrado em Sociologia - Universidade Federal da Paraíba (UFPB), 2012 a.

Segurança pública e a Formação Policial Militar: Os Direitos Humanos como estratégia de controle institucional. Artigo. Revista Estudos em Sociologia, v. 17, $n^{0} 33$, 2012b, p. 447-469.

FRIEDMAN, Milton. Capitalismo e liberdade. São Paulo: Abril Cultural, 1984. 236 p.

INEP. Thesaurus Brasileiro da Educação. Braślila: 2015. Disponível em: http://pergamum.inep.gov.br/ pergamum/biblioteca/pesquisa_thesauro.php?resolution2=1024_1, acesso em 02/08/2015.

INSTITUTO SÃO PAULO CONTRA A VIOLÊNCIA. Conceito de segurança cidadã. São Paulo: 2012. Disponível em: hittp://carceraria.org.br/wp-content/ uploads/2012/07/Seguranca_cidada_Conceitos.pdf, acesso em 25/08/2018.
JACONDINO, Eduardo Nunes. Poder/saber e corpo: os regimes e a construção microfísica da profissionalização da segurança pública. 585 p. Tese de Doutorado em Sociologia - Universidade Federal do Rio Grande do Sul (UFRS), 2011.

HAYEK, F. A. 0 caminho da servidão. São Paulo: Instituto Ludwig von Mises Brasil, 2010. 232 p.

HARVEY, David. Breve historia del neoliberalismo. Madri: Ed. Akal, 2007. 252 p.

0 enigma do capital e as crises do ca-

pitalismo. São Paulo: Ed. Boitempo, 2011. 235 p.

HOBSBAWM, Eric. A era do capital - 1848-1875. São Paulo: Paz e Terra, 1977. 339 p.

KANT DE LIMA, Roberto. Polícia e exclusão na cultura judiciária. Revista Tempo Social, São Paulo, p. 169-183, maio/ 1997.

. Polícia, justiça e sociedade no Brasil: Uma abordagem comparativa dos modelos de administração de conflitos no espaço público. Revista de Sociologia e Política, Rio de Janeiro, n 13, 23-38, nov/1999.

Antropologia, direito e segurança pública: uma combinação heterodoxa. Revista Cuadernos de Antrolopolía Social, Buenos Aires, n 37, p. 43-57, 2013.

KARPINSKI, Marcelo Trevisan. Formação do oficial da polícia militar do Paraná. 127 p. Dissertação de Mestrado em Educação - Universidade Federal do Paraná (UFPR), 2013.

KRUGER, Frederico Marcos. A formação educacional e profissional do policial militar do estado do Paraná: um direito da personalidade. [S. I.] p. Dissertação de Mestrado em Ciências Jurídicas - Centro Universitário de Maringá (CESUMAR), 2011. 
LEAL, G. R. Currículo cultural: uma autoetnografia na Academia De Policia Militar Costa Verde. 151 p. Dissertação de Mestrado em Educação - Universidade Federal do Mato Grosso (UFMT), 2011.

LIMA, Elcimar Maria de Oliveira. Polícia e policiamento: as ambivalências da formação profissional e as práticas policiais na periferia de Belém. 133 p Dissertação de Mestrado em Ciências Sociais - Universidade Federal do Pará (UFPA), 2011.

LIMA, Renato Sérgio de; RATTON, José Luiz; AZEVEDO, Rodrigo Ghiringhelli de. Crime, polícia e justiça no Brasil. São Paulo: Ed. Contexto, 2014. 522 p.

LIMA,Renato Sérgio de; BUENO, Samira; SANTOS, Thandara. Opinião dos policiais brasileiros sobre reformas e modernização da Segurança Pública. In: Fórum de Segurança Pública. SP, FGV, SENASP, 2014.

LOPES, Paola Bonanato. Curso de bacharelado em ciências militares: reconstrução do percurso sócio-histórico, análise da concepção pedagógica e perspectivas. 151 p. Dissertação de Mestrado em Educação - Universidade Federal de Minas Gerais (UFMG), 2011.

LUIZ, Ronilson de Souza. 0 currículo de formação de soldados da polícia militar frente às demandas democráticas. 138 p. Dissertação de Mestrado em Educação - Pontífice Universidade Católica (PUC) de São Paulo, 2003.

Ensino policial militar. 141 p. Tese de Doutorado em Educação - Pontíice Universidade Católica (PUC) de São Paulo, 2008.

MARCONI, Marina de Andrade; LAKATOS, Eva Maria. Fundamentos de Metodologia Científica. São Paulo, Ed. Atlas, 2003.

MÉSZÁROS. Istvan. Para além do capital. São Paulo: Boitempo, 2002. 1096 p.

MIRANDA, Ana Karine Pessoa Cavalcante. Segurança pública, formação policial e mediação de conflitos: novas orientações para a atuação de uma polícia cidadã. 127 p. Dissertação de Mestrado em Políticas Públicas - Universidade Estadual do Ceará (UECE), 2011.

MOURÃO, Maria das Graças Mota; RIBEIRO, Joaquim Rodrigues; SANTOS, Marcio Gomes dos Santos; SOUZA, Moacir Gonçalvez; OLIVEIRA, Reinaldo Barbosa. A percepção dos professores em relação ao sistema de avaliação normatizado pela academia da polícia militar, com foco na avaliação da aprendizagem. Revista Roteiro, Joaçaba, Vol. 39, n 2, Jul-Dez, p. 417-346, 2014.

MUNIZ, Jacqueline. A Crise de Identidade das Polícias Militares Brasileiras: Dilemas e Paradoxos da formação Educacional. Revista Security and Defense Studies Review, Washington, Vol. 1, 177 p, 2001.

MUNIZ, Jacqueline; CARUSO, Haydée; FREITAS, Felipe . Os estudos policiais nas ciências sociais: um balanço sobre a produção brasileira a partir dos anos 2000. Revista Brasileira de Informação Bibliográfica em Ciências Sociais - BIB, v. 1, p. 148-187, 2018.

NASCIMENTO, Iris de Oliveira. Competências de soldado: relações de gênero e formação profissional na polícia militar. 159 p. Dissertação de Mestrado em Educação - Universidade Federal da Paraíba (UFPB), 2013.

PEREIRA Jr., Olimpio Garcia. Gestão por competências: formação dos gestores de segurança pública para o interior de Minas Gerais; uma análise crítica. 90 p. Dissertação de Mestrado em Administração - Faculdade de Estudos Administrativos (FEAD) de Minas Gerais, 2012.

PEREIRA, Benoni Cavalcanti; POLICARPO Jr., José. A formação policial para além da técnica profissional: reflexões sobre uma formação humana. Revista Brasileira de Segurança Pública, Vol. 6, nº 1, Fev-mar/2012, p. 74-88.

PEREIRA, Elio Gomes. 0 ensino na Academia da Polícia Militar em Goiás: matrizes curriculares - mudanças e permanências 1970 2012. 244 p. Dissertação de Mestrado em História - Pontífice Universidade Católica (PUC) de Goiânia, 2013. 
ORGANIZAÇÃO DAS NAÇÕES UNIDAS (ONU). PROGRAMA DAS NAÇÕES UNIDAS PARA O DESENVOLVIMENTO (PNUD). Projeto Segurança Cidadã. 2009. Disponível em: http://www.br.undp.org/content/brazil/pt/ home/projects/seguranca-cidada.html, Acesso em: 31/08/2016.

PINHEIRO, Paulo Sérgio; SADER, Emir. O controle da polícia no processo de transição democrática no Brasil. Temas IMESC, São Paulo, 1985. p. 77-95.

PINTO, Geraldo Augusto. A organização do trabalho no século XX: taylorismo, fordismo e toyotismo. São Paulo: Expressão Popular, 2007. 80 p.

PONCIONI, Paula. Tendências e desafios na formação profissional do policial no Brasil. Revista Brasileira de Segurança Pública, ano 1, n. 1, p. 22-31, 2007.

Políticas públicas para a educação policial no Brasil: propostas e realizações. Estudos sociológicos, Araraquara, v.17, n.33, p.315-331, 2012.

. 0 modelo policial profissional e a formação profissional do futuro policial nas academias de polícia do estado do Rio de Janeiro. Revista Sociedade e Estado, Brasilia, Vol. 20, nº 3, Set-Dez/2005.

REINER, Robert. A política da polícia. Tradução: Jacy Cardia Ghirotti e Maria Cristina Pereira da Cunha Marques. Série: Polícia e Sociedade, Vol. 11, Núcleo de Estudos da Violência da Universidade de São Paulo (NEV/USP). São Paulo, Edusp, 2004, 376 p.

ROMANOWSKY, Joana Paulin; ENS, Romilda Teodora. As pesquisas denominadas do tipo "estado da arte" em educação. Revista Diálogo Educacional, Curitiba, Vol. 6, $n^{0}$ 19, Set-dez/2006, p. 37-50.

RUDNICKI, Dani. A formação social de oficiais da polícia militar: análise do caso da academia da Brigada Militar do Rio Grande do Sul. 365 p. Tese de Doutorado em Sociologia - Universidade Federal do Rio Grande do Sul (UFRS), 2007.
- O ingresso de bacharéis em direito na po-

lícia militar gaúcha. Revista Sociologias, Porto Alegre, Ano 10, ח 20, p. 108-137, Jul-Dez, 2008.

SANCHES, Clives Pereira. Nova matriz curricular do curso de formação de oficiais: uma adequação ao perfil profissiográfico do chefe de polícia ostensiva da PMGO. Revista Brasileira de Estudos de Segurança Pública, Goiânia, Vol.1, n01, 2008.

SANTANA, Douglas Freire. 0 ensino militar estadual além da lei de diretrizes e bases da educação nacional. Revista Brasileira de Estudos de Segurança Pública, Goiânia, Vol. 6, n01, 2014, p. 33-41.

SANTOS, Daniel Limeira. Cultura, aprendizagem organizacional e desenvolvimento de competências: a formação de policiais militares para o exercício da profissão em uma sociedade democrática. 144 p. Dissertação de Mestrado em Gestão - Universidade Federal da Paraíba (UFPB), 2014.

SANTOS, Vera Lúcia Bezerra. Formação de oficiais da PMMA: uma visão paralática acerca da segurança pública. 223 p. Dissertação de Mestrado em Administração - Fundação Getúlio Vargas (FGV) do Rio de Janeiro, 2012.

SEVERINO, Antônio Joaquim. Metodologia do trabalho científico. São Paulo, Ed. Cortez, 23ª Edição, 2007, 304 p.

SOUZA, Adilson Paes. A educação em direitos humanos na Polícia Militar. 156 p. Dissertação de Mestrado em Direito - Universidade de São Paulo (USP), 2012.

SILVA, Antônia Maria dos Santos. A formação de praças da polícia militar do Piauí: uma análise a partir da prática pedagógica do oficial formador. 163 p. Dissertação de Mestrado em Educação - Universidade Federal do Piauí (UFPI), 2012. 
SILVA, João Batista. A violência policial militar e o contexto da formação profissional: um estudo sobre a relação entre violência e educação no espaço da Polícia Militar no Rio Grande do Norte. 128 p. Dissertação de Mestrado em Ciências Sociais - Universidade Federal do Rio Grande do Norte (UFRN), 2009.

Os novos parâmetros educacionais das polícias militares brasileiras: um exercício de análise a partir da formação profissional dos soldados da Polícia Militar do Estado do Rio Grande do Norte, na primeira década do século XXI. Revista Brasileira de Segurança Pública, São Paulo, Vol. 6, nº 1, Fev-Mar, p. 48-73, 2012.

SILVA, Robson Rodrigues da. Entre a caserna e a rua: 0 dilema do pato. Uma análise antropológica da instituição policial militar a partir da Academia de Polícia Militar Dom João VI. 208 p. Dissertação de Mestrado em Antropologia - Universidade Federal Fluminense (UFF), 2009.

SILVA, Rosalinde. Formação de oficiais na polícia militar do estado da Bahia para a mediação de conflitos sociais. 137 p. Dissertação de Mestrado em Desenvolvimento Humano - Fundação Visconde de Cairú (FVC), 2012.

SILVA, Sairo Rogério da Rocha. Os saberes em potencial da atividade policial ostensiva: sistematizando modelos a partir da experiência potiguar. 218 p. Tese de Doutorado em Educação - Universidade Federal do Rio Grande do Norte (UFRN), 2007.

SOUZA, Adilson Paes. A educação em direitos humanos na Polícia Militar. 156 p. Dissertação de Mestrado em Direito - Universidade de São Paulo (USP), 2012.
SOUZA, José dos Santos. 0 sindicalismo brasileiro e a qualificação do trabalhador. $2^{2}$ Edição. Bauru: Editora Práxis, 2015a. 198 p.

A formação do trabalhador no contexto da reconfiguração do trabalho, da produção e dos mecanismos de mediação do conflito de classe. Revista Contemporânea de Educação Vol. 10, ח 20, p. 273-290, jul.-dez./2015b.

SOUZA NETO, Cláudio Pereira. A segurança pública na Constituição Federal de 1988: conceituação constitucionalmente adequada, competências federativas e órgãos de execução das políticas. In: SOUZA NETO et al (orgs.). Vinte anos da Constituição Federal de 1988. Rio de Janeiro: Lumen Juris, 2009.

VEIGA, Célia Cristina P. S. Reforma Administrativa do Estado, segurança pública e Formação de Soldados da PMERJ. Nova Iguaçu (RJ): 2016. 353 f. Dissertação [Mestrado em Educação] - Programa de Pós-graduação em Educação, Contextos Contemporâneos e Demandas Populares, Universidade Federal Rural do Rio de Janeiro.

VEIGA, Célia Cristina P. S. ; SOUZA, José dos Santos. Formação inicial de soldados da Polícia Militar do Estado do Rio de Janeiro no contexto da reforma gerencial do Estado. Trabalho Necessário, vol. 16, ח²9, p. 115-137, Jan.jun./2017. 



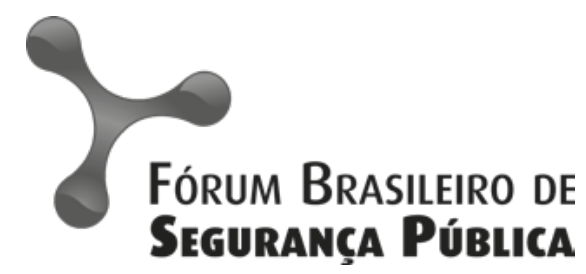

ISSN 1981-1659 